\title{
The Importance of a Medium-Term Budgetary Framework in Enhancing the Sustainability of Public Finances
}

\author{
${ }^{1}$ Muhammad Khalil, ${ }^{2}$ Naveed Ahmad, ${ }^{3}$ Muhammad Nouman Shafique, \\ ${ }^{4}$ Hussain Ahmad, ${ }^{2}$ Khalil- Ur- Rehman, ${ }^{2}$ Raza Illahi \\ ${ }^{1}$ Master in Business Administration, Federal Urdu University of Art, Science and Technology, \\ Islamabad \\ ${ }^{2}$ Department of Business Administration, Lahore Leads University, Pakistan \\ ${ }^{3} \mathrm{Ph}$.D Scholar Preston University, Islamabad \\ ${ }^{4}$ Federal Urdu University of Art, Science and Technology, Islamabad \\ E-mail address: Mkhalil_fuu@yahoo.com, naveeddgk2010@gmail.com
}

\begin{abstract}
Keywords: medium-term budgetary framework; quality of public finances; sustainability of the fiscal system; fiscal governance
\end{abstract}

\begin{abstract}
Globalization has changed traditional systems to scientific systems rapidly. This reform took place every organizational process. Fiscal reforms are the major reforms in the organization. The objectives of fiscal reform is to enhance the quality of fiscal governance and public finance. The fiscal reform also consolidate superior budgetary resources through better disciplinary fiscal policies. These disciplined fiscal policies can be followed by the organizational and legislative measurements. It will leads to the introduction and establishment of new and independent fiscal rules. Now fiscal strategies moving towards the multi-annual budget system. The implementation of multi-annual budget system introduced the medium term budgetary system. The basic aim of this study is to introducing the importance of implementation of medium term budget system and the role of this budget system in public organizations. Fiscal management policies and tools plays important role in the sustainability of public finance in nations.
\end{abstract}

\section{INTRODUCTION}

Today, International competitiveness is the biggest challenge in national economies. It is comprised to establish and support between social and economic progress and development that will enhance the financial framework. This financial frame work will enhance the social and economic progress continuously for private and public financing organizations especially in Europe and international context (Stanciu, 2012 ).

National financial rules and policies will provide the ways to public organizations to sustainability of national finance. These fiscal rules will imposed in the organizations to operate in the realities. This real time and situation policies and rules of nations will also enhance the sustainability and growth of economic factors of the nation. These policies not only provide the frame work to operate in local area but it is also support the organizations to analyze the needs of financial suitability across the national boundaries. This framework also provide the guideline to make and enhance the international relations with other organizations operating in different countries. Public finance is not a single subject, it is compromised on different and complex and current situations which are integrated to many other factors (Romania, 2009 ).

National budget is comprises of social contribution of public, different public control resources and major of national budget will be collected from the taxes from the public. This national budget will provide the finance to different public organizations to make their strategies especially fiscal policies of nation. Government budget not only spent on the financing of government organizations but it is also effect on the social and economic life pattern of the public. The conclusive intention of the government budget spending is to enhance the quality and living 
standard of public through their financing activities to provide loans and financing them from collected taxes especially in Europe and generally all over the world (Stanciu, 2012 ).

Sustainability of public finance is depends upon the tax system of the nation. If the tax system and its components are strictly followed in the country then the sustainability of finance will remains long and government should invest in the different projects to facilitate the public through economic development. Specific objective of every country should be achieved through fulfilling of the national development needs by the implementing the different fiscal policies which will leads to the better achievement of public finance. It is established that if better fiscal policies and strategies are formulated and implemented then the development of country enhance through the economic development (Rogerson, 2015).

Success of organizations is possible only when the implementation of good strategies is possible. Only the formulation of good strategy is not achieved until it is implemented as they are developed. In the same way the consistency and predictability of fiscal policy is achieved through the implementation of fiscal strategies. These fiscal policies also encourage foreign investors to invest in country by safely funding their investment in the country. It is ensured the investors that their investment is placing in a developed framework which will lead the economic development of their funds to increase their profit. And the country provide suitable and growth worthy environment for them to invest (Lledó \& Poplawski-Ribeiro, 2013).

Annual budget preparation is the essential component of the fiscal policy. Every fiscal policy must prepare the annual budget of the country. This annual budget is not only concerning the current year. This budget will be consist if this budget will be consistent with the last 3 to 4 years. Budget consistency will show the economic stability and growth of the country. So, annual budget consistency is important in the formulation of fiscal strategies. This consistency of budget will be developed if annual budget policy is divided in the medium-term budget framework (MTBF) to achieve the fiscal policy goals in all over the world (Vlaicu, Verhoeven, Grigoli, \& Mills, 2014).

Numerous advantages like the accountability, consistency, strengthen the fiscal discipline and increase in the transparency of the fiscal system can be achieved through the implementation of medium-term budgetary framework (MTBF). These are the different budgetary processes that are implemented in different countries of the world to enhance the fiscal framework. This medium-term budgetary framework (MTBF) will be introduces all over the world in the period of crises. A lot of fiscal crises like public debt level or budget deficits can be resolved through the implementation of medium-term budgetary framework (Romania, 2009 ).

Today, it is compulsory for all over the world to adopt medium-term budgetary framework to consolidate the fiscal policies of every country. Because in current situation every country is facing the economic crises and these crises has been hit the highest level of economic crises. So, in these crises the medium-term budgetary framework is necessary to adopt. In our country the budgetary and fiscal policies has never been adopted. Because out fiscal policies has less consistency and the transparency is also required. Our country should try to meet the standards of fiscal and economic policies with European Commission to promote our fiscal policies which will encourage investors from other countries (Commission, 2015).

\section{MEDIUM-TERM BUDGETARY FRAMEWORK}

Global financial crises can be minimized through the adoption of recommendations of different international fiscal policy development bodies such as World Bank, European Commission International Monetary Fund and OECD. They will recommend each nation to adopt and align the standardized European fiscal policy. They will also recommend nations to bind a treaty with the European fiscal policy making organization to standardize their local fiscal policies to minimize the crises which are facing the nations. Effectiveness of national fiscal policies can be enhanced through the continuous improvement in public finances. And the quality of these fiscal policies should measure continuously (Romania, 2009). 
Stability and Growth Pact of European Commission has been revised in 2005. The main reason to revise this policy is to ensure and enhance the quality of European fiscal policy. This pack will also enhance the environment of the nation to invest in different businesses because nation will provide the more suitable for economic stability and development. This pack will also provide guidelines for the nation to formulate national fiscal strategies to enhance the quality. It will also enhance the predictability and transparency in the national fiscal policies. According to European Commission fiscal governance is the fundamental component of public finances (Tiţa, Oţetea, \& Banu, 2014).

National fiscal governance is comprises on the set of fiscal policies, strategies, rules and budgetary regulations of the country. It is compromises of the set of rules and regulations start from the procedures of preparation of budget, adoption of budget and the monitoring process of budget. Quality of fiscal governance can be achieved through the implementation of existing fiscal strategies, policies, rules and procedures. These fiscal strategies will also further implementing with the support of fiscal laws developed by the nation. These fiscal policies will be implemented with the support of government and the independent Fiscal Council which will ensure the implementation of fiscal policies in the country (Romania, 2009 ).

Fiscal governance is compromised on these three dimensions.

1. Fiscal council

2. Fiscal policy

3. Medium-term budget framework (MTBF)

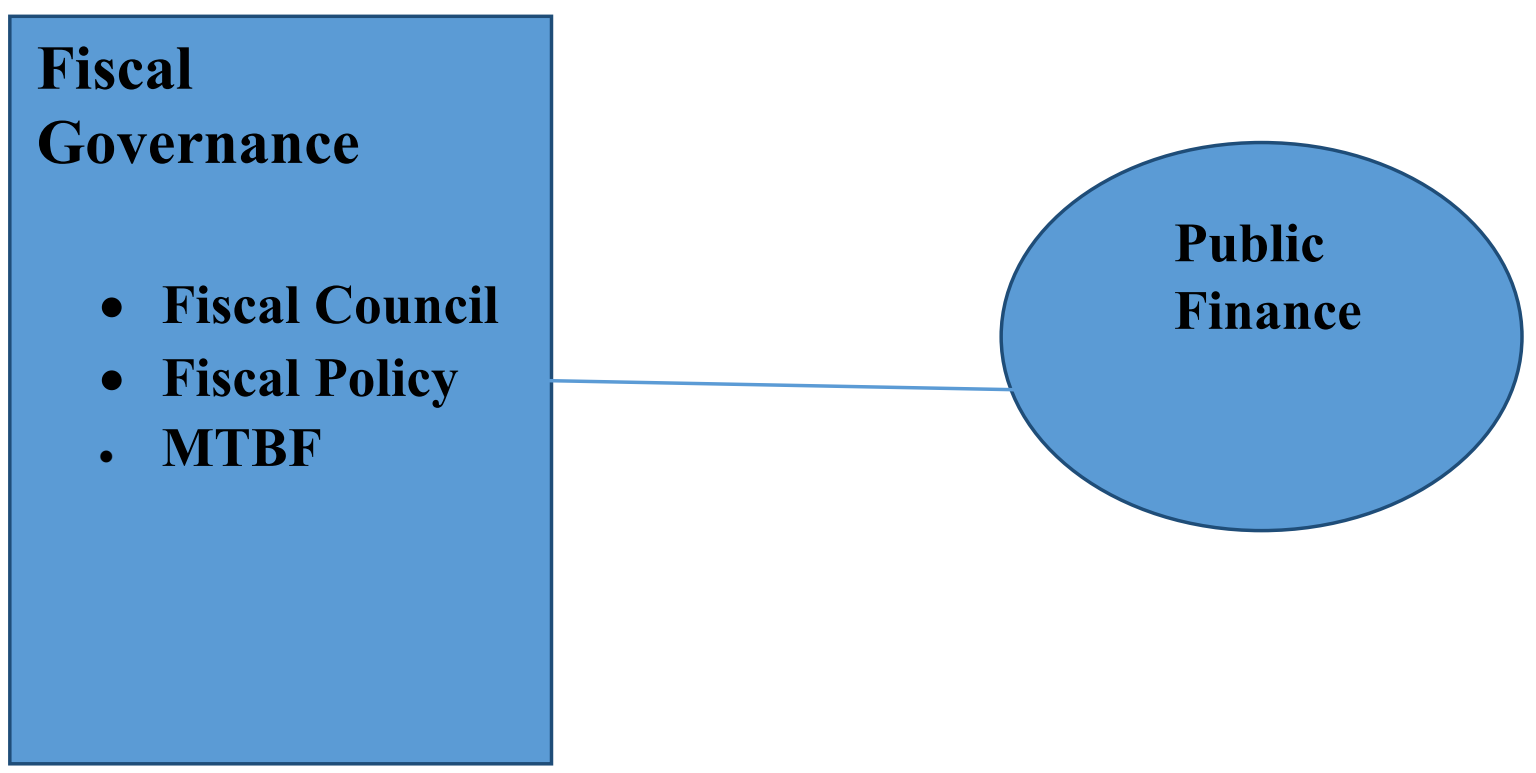

The medium-term budgetary framework is the essential component of fiscal governance. The medium-term budgetary framework has the following advantages.

- The medium-term budgetary framework is positively associated with the awareness of business environment because it will create the transparency in the fiscal policies.

- The medium-term budgetary framework will improve the management of public expenditure and also improve the public budgetary tools.

- The medium-term budgetary framework will also provide the clear way of responsibilities of fiscal policies.

- The medium-term budgetary framework will also align the fiscal policies with European fiscal system and also brings reforms in the fiscal policies.

- The medium-term budgetary framework will also increase ensure the continuity in adoption of fiscal policies in macroeconomic environment. 
- The medium-term budgetary framework will also increase the continuity of previous fiscal policies and also follow the objective of fiscal policies by the allocation of public resources effectively.

- The medium-term budgetary framework will also modernize the old the techniques of fiscal budget to program-based budget which will clearly shows the infrastructure development, employment development and economic growth.

The European Commission has developed the Stability and Growth Pact to ensure the quality of fiscal policies. The major component of fiscal policy is the medium-term budget framework. But medium-term budget framework is not the new concept. It is adopted in many countries before the development of the Stability and Growth Pact. Member of European Union has been implementing this medium-term budget framework in public finance a long time before the introduction of Stability and Growth Pact (Commission, 2015).

In the same context Sweden has adopted the new medium term budget framework in 1997. The reason to implement this medium term budget framework is the economic, financial and fiscal crises in the nation. It will spread all over the nation in the early of 90's. Furthermore Netherlands has adopted the multiannual budgetary system in 1994. It will also introduces in other countries like in Finland in 1995 it is introduced to overcome the financial and fiscal crises. The rudimentary goal of this system is to develop the standardized financial rules and policies to bring the reforms in the fiscal development policy in the fiscal stability to minimize the economic recession (Tiţa et al., 2014).

The first step of medium-term budgetary framework is taken in the European Union by the United Kingdom in 1998. Because they have adopted two fiscal rules. First is called sustainability investment rule and the second is called the golden rule. These are the elementary rules and play the back bone role of public expenditure. These public expenditures will planned to sustain the fiscal policy for three years. Spanish has been adopted this model of medium-term budgetary framework in 2001 to take in practice from the adoption of fiscal model from English. The basic aim for the adoption of this model from English is to develop a balance in budget and it will also minimize the deficits from the budget (Tiţa et al., 2014).

Medium-term budgetary framework is now become the prerequisite in the fiscal practices in European Union to establish national governments fiscal policies. It is the reality of public policy to implement the modern budgetary tools in the budgetary management process. It is not imposed that the standardized alignment of common fiscal policies to the national fiscal policies. These policies has the common goals and compatibilities of national fiscal policies towards the implementation of standardized European Union fiscal policies through different treaties. Medium-term budgetary frameworks has approved and implemented in different countries that will leads to enhance the mechanism of logistic and traditional fiscal policies (Barbier \& Burgess, 2015).

Medium-term budgetary frameworks has been divided in to two main categories. This categorization is based on the continuity in the budget in the different countries all over the world. First main category of medium-term budgetary frameworks is the flexible medium-term budgetary frameworks. This framework will refer that's the overall objectives can be of the country can be adjusted on the development of economies or the fiscal policies of the country. So, it is the flexible and will change as the fiscal policy will change. While the second category of medium-term budgetary framework is the fixed medium-term budgetary framework. It refer as constant or remain the unchanged until all the time horizon. It will only change when the major change is occur it may the hyper economic recession or the change in government. Otherwise it remains the constant all over the time (Solomon, 2012). 


\section{Conclusions}

Medium-term budget framework is the process to adopt by any nation. First challenge will face in the development of medium-term budget framework, it will include all the macroeconomic models used in the budgetary process to use as the indicators to forecast the economic and fiscal development models.

Second challenge of medium-term budget framework is to develop different fiscal strategies to enhance the effectiveness and also ensure the predictability and transparency of the fiscal system. This system will also predict the public spending, public debt, budget deficit and relevant revenues collected from taxes and other ways of income generation.

Medium-term budget framework will also enhance the fiscal governance quality. It will also develop the measurement of logistic and institutional measure of fiscal policies through different fiscal rules and laws. Fiscal governance become more prioritized and it will be more characterized in the legislative measures at institutional as well as legislative level. It is consists of different laws on the developing the long term fiscal strategies to shift from the multi-annually budgetary programs. This strategies will implement in medium-term budget framework. It will also introduces new fiscal laws which will be followed strictly. It will also ensure the effectiveness and efficiency of medium-term budget framework laws in the nations to encourage the foreign investors.

In our country we have political instability which is effecting to fail in the introduction of the medium-term budget framework due to the lack of consistency and adoption of the fiscal policies. This political instability will also enhance the lack of clear fiscal strategies especially in taxes collection and other government collections from the public. These are the main reasons which will restrict the implementation of medium-term budget framework or the multi-annual budgeting in our nation.

Medium-term budget framework is a complex issue which is connected with annual budget, budgetary process, fiscal rules and fiscal strategies. These are the indicators of macroeconomics. Effectively implementation of medium-term budget framework ensure the fiscal discipline.

\section{References}

[1] Andersen, T. M. (2012). Fiscal sustainability and demographics - Should we save or work more? Journal of Macroeconomics, 34(2), 264-280. doi: http://dx.doi.org/10.1016/j.jmacro.2012.01.001

[2] Annicchiarico, B., Giammarioli, N., \& Piergallini, A. (2012). Budgetary policies in a DSGE model with finite horizons. Research in Economics, 66(2), 111-130. doi: http://dx.doi.org/10.1016/j.rie.2012.01.001

[3] Armstrong, P. (2011). Budgetary bullying. Critical Perspectives on Accounting, 22(7), 632643. doi: http://dx.doi.org/10.1016/j.cpa.2011.01.011

[4] Aslanli, K. Fiscal sustainability and the State Oil Fund in Azerbaijan. Journal of Eurasian Studies(0). doi: http://dx.doi.org/10.1016/j.euras.2015.03.004

[5] Baldacci, E., Hillman, A. L., \& Kojo, N. C. (2004). Growth, governance, and fiscal policy transmission channels in low-income countries. European Journal of Political Economy, 20(3), 517-549. doi: http://dx.doi.org/10.1016/j.ejpoleco.2003.12.002

[6] Banu, I., Banu, I. M., \& Popescu, M. (2013). Trust in Romanian Fiscal Institutions from the Point of View of Sustainability: A Case Study. Procedia Economics and Finance, 6(0), 604608. doi: http://dx.doi.org/10.1016/S2212-5671(13)00178-0

[7] Barbier, E. B., \& Burgess, J. C. (2015). Sustainable Development: An Economic Perspective. In J. D. Wright (Ed.), International Encyclopedia of the Social \& Behavioral Sciences (Second Edition) (pp. 823-827). Oxford: Elsevier. 
[8] Barrios, S., \& Schaechter, A. (2009). Gauging by numbers: A first attempt to measure the quality of public finances in the EU. European Commission Economic Papers, 382.

[9] Commission, E. (2015). The Commission and its Priorities. from http://ec.europa.eu/index_en.htm

[10] Covaleski, M. A., \& Dirsmith, M. W. (1988). The use of budgetary symbols in the political arena: An historically informed field study. Accounting, Organizations and Society, 13(1), 124. doi: http://dx.doi.org/10.1016/0361-3682(88)90023-2

[11] de Jong, E. (2015). Culture and Economic Development. In J. D. Wright (Ed.), International Encyclopedia of the Social \& Behavioral Sciences (Second Edition) (pp. 528-534). Oxford: Elsevier.

[12] Ductor, L., \& Grechyna, D. (2015). Financial development, real sector, and economic growth. International Review of Economics \& Finance, 37(0), 393-405. doi: http://dx.doi.org/10.1016/j.iref.2015.01.001

[13] El Anshasy, A. A., \& Katsaiti, M.-S. (2013). Natural resources and fiscal performance: Does good governance matter? Journal of Macroeconomics, 37(0), 285-298. doi: http://dx.doi.org/10.1016/j.jmacro.2013.05.006

[14] Gabriela, B. (2009). Economic and Monetary Union. University AGORA Publisher, Bucharest.

[15] Kaplanoglou, G., \& Rapanos, V. T. (2013). Fiscal Deficits and the Role of Fiscal Governance: The Case of Greece. Economic Analysis and Policy, 43(1), 5-27. doi: http://dx.doi.org/10.1016/S0313-5926(13)50001-4

[16] Ko, J.-H., \& Morita, H. (2015). Fiscal sustainability and regime shifts in Japan. Economic Modelling, 46(0), 364-375. doi: http://dx.doi.org/10.1016/j.econmod.2015.02.008

[17] Komal, R., \& Abbas, F. (2015). Linking financial development, economic growth and energy consumption in Pakistan. Renewable and Sustainable Energy Reviews, 44(0), 211-220. doi: http://dx.doi.org/10.1016/j.rser.2014.12.015

[18] Kruss, G., McGrath, S., Petersen, I.-h., \& Gastrow, M. (2015). Higher education and economic development: The importance of building technological capabilities. International Journal of Educational Development, 43(0), 22-31. doi: http://dx.doi.org/10.1016/j.ijedudev.2015.04.011

[19] Lledó, V., \& Poplawski-Ribeiro, M. (2013). Fiscal Policy Implementation in Sub-Saharan Africa. World Development, 46(0), 79-91. doi: http://dx.doi.org/10.1016/j.worlddev.2013.01.030

[20] M, M., \& C.F., C. (2006). Taxation in Europe in the early third millennium. Rosetti Publisher, Bucharest.

[21] Mahdavi, S., \& Westerlund, J. (2011). Fiscal stringency and fiscal sustainability: Panel evidence from the American state and local governments. Journal of Policy Modeling, 33(6), 953-969. doi: http://dx.doi.org/10.1016/j.jpolmod.2011.08.015

[22] Meng, X., \& Zhang, L. (2011). Democratic participation, fiscal reform and local governance: Empirical evidence on Chinese villages. China Economic Review, 22(1), 88-97. doi: http://dx.doi.org/10.1016/j.chieco.2010.09.001

[23] Miyazaki, T. (2014). Fiscal reform and fiscal sustainability: Evidence from Australia and Sweden. International Review of Economics \& Finance, 33(0), 141-151. doi: http://dx.doi.org/10.1016/j.iref.2014.04.002 
[24] Ongaro, E., Ferré, F., \& Fattore, G. The fiscal crisis in the health sector: Patterns of cutback management across Health Policy $(0)$. doi: http://dx.doi.org/10.1016/j.healthpol.2015.04.008

[25] Pina, Á. M., \& Venes, N. M. (2011). The political economy of EDP fiscal forecasts: An empirical assessment. European Journal of Political Economy, 27(3), 534-546. doi: http://dx.doi.org/10.1016/j.ejpoleco.2011.01.005

[26] Pradhan, R. P., Arvin, M. B., \& Norman, N. R. (2015). The dynamics of information and communications technologies infrastructure, economic growth, and financial development: Evidence from Asian countries. Technology in Society, 42(0), 135-149. doi: http://dx.doi.org/10.1016/j.techsoc.2015.04.002

[27] Ramadhan, S. (2009). Budgetary accounting and reporting practices in Bahraini governmental units: An empirical study. International Business Review, 18(2), 168-183. doi: http://dx.doi.org/10.1016/j.ibusrev.2009.01.001

[28] Ravago, M.-L. V., Balisacan, A. M., \& Chakravorty, U. (2015). Chapter 1 - The Principles and Practice of Sustainable Economic Development: Overview and Synthesis. In A. M. Balisacan, U. Chakravorty \& M.-L. V. Ravago (Eds.), Sustainable Economic Development (pp. 3-10). San Diego: Academic Press.

[29] Rogerson, C. M. (2015). Local Economic Development. In J. D. Wright (Ed.), International Encyclopedia of the Social \& Behavioral Sciences (Second Edition) (pp. 279-283). Oxford: Elsevier.

[30] Romania, E. I. o. (2009 ). Public Finance: Introducing the medium term fiscal-budgetary framework. Strategy and Policy Studies, Bucharest(1).

[31] Samargandi, N., Fidrmuc, J., \& Ghosh, S. (2015). Is the Relationship Between Financial Development and Economic Growth Monotonic? Evidence from a Sample of Middle-Income Countries. World Development, 68(0), 66-81. doi: http://dx.doi.org/10.1016/j.worlddev.2014.11.010

[32] Schalck, C. (2014). Fiscal behaviours in EMU countries: A dynamic approach. Economic Analysis and Policy, 44(3), 345-354. doi: http://dx.doi.org/10.1016/j.eap.2014.09.002

[33] Solomon, A. G. (2012). Impact of Euro-area Accession on Fiscal and Budgetary Policy in Romania. Procedia - Social and Behavioral Sciences, 62(0), 733-738. doi: http://dx.doi.org/10.1016/j.sbspro.2012.09.124

[34] Stanciu, M. (2012 ). European Governance and public budgets in crisis The Quality of Life, 23(3).

[35] Swaroop, V., Jha, S., \& Sunil Rajkumar, A. (2000). Fiscal effects of foreign aid in a federal system of governance: The case of India. Journal of Public Economics, 77(3), 307-330. doi: http://dx.doi.org/10.1016/S0047-2727(00)00070-0

[36] Tiţa, C., Oţetea, A., \& Banu, I. (2014). The Importance of a Medium-term Budgetary Framework in Enhancing the Sustainability of Public Finances in Romania. Procedia Economics and Finance, 16(0), 270-274. doi: http://dx.doi.org/10.1016/S22125671(14)00800-4

[37] Vlaicu, R., Verhoeven, M., Grigoli, F., \& Mills, Z. (2014). Multiyear budgets and fiscal performance: Panel data evidence. Journal of Public Economics, 111(0), 79-95. doi: http://dx.doi.org/10.1016/j.jpubeco.2013.12.011

[38] Vorontsov, D., Shikhalev, A., \& Semushina, K. (2015). Using of Cultural Heritage in the Socio-economic Development Strategy of the EU Regions. Procedia - Social and Behavioral Sciences, 188(0), 163-169. doi: http://dx.doi.org/10.1016/j.sbspro.2015.03.358 
[39] Walker, S. P., \& Carnegie, G. D. (2007). Budgetary earmarking and the control of the extravagant woman in Australia, 1850-1920. Critical Perspectives on Accounting, 18(2), 233261. doi: http://dx.doi.org/10.1016/j.cpa.2005.10.003

[40] Yakita, A. (2014). Involuntary unemployment and sustainability of bond-financed fiscal deficit. Journal of Macroeconomics, 41(0), 79-93. doi: http://dx.doi.org/10.1016/j.jmacro.2014.05.003

[41] Yuan, J., Luo, D., \& Feng, L. (2015). A review of the technical and economic evaluation techniques for shale gas development. Applied Energy, 148(0), 49-65. doi: http://dx.doi.org/10.1016/j.apenergy.2015.03.040 